\title{
BIBLIOGRAPHY
}

\section{Selected Bibliography of Works on Political Culture*}

\section{The Interpretation of American Political Culture}

The study of political culture is more than a way of understanding the social and political foundations of the legal system. It is also a way to understand how lawyers conduct their daily lives and what influences inform their practice. Early American lawyers were strongly influenced by the classics, seeking to model their oratory on the eloquence of Cicero, as Stephen Botein noted in his article, Cicero As Role Model For Early American Lawyers: A Case Study in Classical "Influence," 73 The Classical J. 313 (1973). Maxwell Bloomfield's study of American lawyers, American Lawyers in a Changing Society (1976), explores not only cultural restraints upon lawyers and the perception society has of lawyers, but also the role cultural forces played in transforming the bar from an elite group of classicists into a rougher but more egalitarian community. Robert A. Ferguson's Law and Letters in American Culture (1984) demonstrates how the legal imagination of the Republic's first generations of lawyers was a vital part of America's literary tradition, and how that tradition in turn shaped legal and political understandings.

Several of the recent works studying American political culture reveal the influence of interpretive anthropology and semiotics. The legal anthropologist Lawrence Rosen has applied the methods and insights of anthropology to issues relevant to AngloAmerican law in his essay, Intentionality and the Concept of the Person, in J. Roland Pennock and John W. Chapman, eds., Nomos XVII: Criminal Justice 52 (1985). The late Robert M. Cover imported anthropological and semiological ideas into constitutional

* This bibliography was compiled by editors James Barry, John Duffy, Christopher Eisgruber, Gregory Mark, and Richard Murphy of The University of Chicago Law Review. 
theory, and used those ideas in his Nomos and Narrative, 97 Harv.L.Rev. 4 (1983) to describe how legal precepts interacted with broader cultural norms to generate conflicting and overlapping spheres of legal meaning. An earlier work addressing similar themes is William F. Harris II's Bonding Word and Polity, 76 Am.Pol.Sci.Rev. 34 (1982), which treats the Constitution as a fusion of two different orders of composition, one literary and one political, and examines how this fusion structures interpretation of the American attempt to "speak into being" a new political regime. David I. Kertzer's, very recent book, Ritual, Politics, and Power (1988), puts the anthropological perspective to another use, analyzing the significance of ritual in the politics of various nations, including the United States.

The interpretive paradigm has been prominent in the study of the political implications of Puritan culture. Of seminal importance in this field are the works of Sacvan Bercovitch, including The Puritan Origins of the American Self (1975) and The American Jeremiad (1978). Both works argue that the nature and forms of Puritan rhetoric were of major significance in shaping the American mind. A new book by Donald Weber, Rhetoric and History in Revolutionary New England (1988), engages Bercovitch's arguments in the course of examining the interaction of religion and politics within the "ritual dimension of the American Revolution."

Antebellum America has been the focus of several very recent influential studies of culture and politics. Jean H. Baker's Affairs of Party: The Political Culture of Northern Democrats in the MidNineteenth Century (1983) demonstrates that party affiliation was an important source of identity for nineteenth century Americans, shaping cultural attitudes and views of democracy. In the same vein, Daniel Walker Howe examines the cultural identity and impact of the Whigs, the loyal opposition in the age of the Jacksonian Democrats, in The Political Culture of the American Whigs (1979). Anne Norton argues, in Alternative Americas: A Reading of Antebellum Political Culture (1986), that cultural differences defined the conflict between North and South in antebellum America. Russel Blaine Nye's earlier study, Society and Culture in America: 1830-1860 (1974), looks to Romanticism, economic growth and sectional division as sources of American identity.

Leo Marx, whose seminal role in the development of the interdisciplinary American studies movement is well known, has recently published The Pilot and The Passenger: Essays on Literature, Technology, and Culture in the United States (1988). The collection includes works written over the last thirty years span- 
ning a wide range of topics in cultural interpretation throughout American history. Late nineteenth century America was home to experimentative and imaginative visions of the future of the American polity in particular and its culture in general. John L. Thomas explores three of the most prominent visionaries within American political culture in his Alternative America: Henry George, Edward Bellamy, Henry Demarest Lloyd and the Adversary Tradition (1983). Alan Trachtenberg's The Incorporation of America: Culture and Society in the Gilded Age (1982) suggests that incorporation serves as a metaphor by which we can understand the era that led America into the twentieth century.

Several scholars have attempted to understand liberalism as a form for political culture-rather than as simply a political theory-and to specify the nature and varieties of American liberalism. J. David Greenstone has, in Political Culture and American Political Development: Liberty, Union, and the Liberal Bipolarity, in 1 Stud.in Am.Pol.Dev. 1 (1986), explored the strands of liberalism that shaped political conflict in the Northern United States just before the civil war. Greenstone has also edited a volume of essays, Public Values \& Private Power in American Politics (1982), on the manner in which the tension between self-interest and public values in the American polity shapes American political action. John Patrick Diggins, in his The Lost Soul of American Politics (1984), challenges the assumption that Lockean political premises and Calvinist sentiments were incompatible. Diggins argues that the Calvinist ethic provided an escape from some of the dilemmas posed by liberalism in the first half of the nineteenth century.

The current scholarly debate about the triumph of liberalism over republicanism in American political culture includes Isaac Kramnick's The "Great National Discussion": The Discourse of Politics in 1787, $45 \mathrm{Wm}$. \& Mary Q. 3 (1988), arguing that competing political paradigms, including but not limited to republicanism and liberalism, shaped a multifarious political discourse essential to the founding. Morton Horwitz suggests that elements of republicanism have been preserved, despite the dominance of liberalism since the adoption of the Constitution. Morton J. Horwitz, Republicanism and Liberalism in American Constitutional Thought, 29 Wm. \& Mary L.Rev. 57 (1987). Horwitz also commented upon the character of American liberalism in an earlier essay analyzing Tocqueville's understanding of majoritarianism. Morton J. Horwitz, Tocqueville and the Tyranny of the Majority, 28 Rev.Pol. 293 (1966). G. Edward White has, in his recently issued volume of the Holmes Devise History of the Supreme Court, applied the inter- 
pretive study of republican culture to the examination of the Marshall Court. G. Edward White, The Marshall Court and Cultural Change, 1815-35 (1988). The opening chapters of White's work are of particular relevance to the topic of law and American political culture.

Other scholars have interpreted American culture in ways that call into question both the pervasiveness and the legitimacy of the American liberal tradition. Michael Paul Rogin's books and essays apply incisive psychological perceptions to criticize American politics. His recent Ronald Reagan, the Movie, And Other Episodes in Political Demonology (1987) argues that American leaders appeal to the countersubversive imagination of the people in order to suppress groups outside the political mainstream. Ann Douglas's The Feminization of American Culture (1977) examines connections between Calvinism, sentimentalism, and Victorianism in America, arguing that the creation of feminized mass culture has in some ways perpetuated patriarchy in America.

Michael Kammen has been a prolific contributor to the study of the cultural significance of the Constitution and constitutional ideas. His A Machine That Would Go of Itself (1986) deals with the cultural meaning of the Constitution in the mind of the American people, and his Spheres of Liberty (1986) discusses the changing and divergent uses of the word liberty throughout American history.

\section{Sources: Theory and Predecessors}

Generations of commentators have drawn on the telling insights of Alexis de Tocqueville's famous Democracy in America (1835). Also of seminal importance to interpreters of American political culture is Louis Hartz's The Liberal Tradition in America (1955), the classical twentieth century text defining liberalism as the dominant mode of political discourse in America. A synthetic work covering the entire range of American history, it both serves as the scholarly standard against which other works are measured and remains an interpretation to be reckoned with for analysts of political meaning in this country. Richard Hofstadter, in a work that antedated Hartz's, however, had noted that earlier scholars of American politics had emphasized conflict, underplaying the powerful "common ground, a unity of cultural and political tradition" that stood as the core of our political heritage. The American Political Tradition And the Men Who Made It (1948). America before the Civil War has been the focus of some of the most innovative scholarship in recent decades. Perry Miller's The Life of The Mind 
in America From the Revolution to the Civil War (1965) is the forerunner of the work of scholars who have delved into the relationship between law and letters in America. Bernard Bailyn advanced a powerful new perspective on Revolutionary era thought with his The Ideological Origins of the American Revolution (1967), a work that has paved the way for numerous other studies focusing on political language and ideology. J.G.A. Pocock's Politics, Language and Time (1960) develops his understanding of the role of language in channeling and defining political thought in essays devoted both to theory and historical example.

Two anthropologists have inspired much of the work interpreting American political culture. Clifford Geertz is frequently cited for his development of the interpretive study of culture in anthropology, and in particular for his treatment of thought as composed of symbol systems used to order political and other circumstances. Geertz's essays are collected in The Interpretation of Cultures (1973) and in Local Knowledge (1983). The title essay of the latter work deals explicitly with the relationship between anthropology and American law. Victor W. Turner's The Ritual Process (1969), examining the symbolic structure of ritual and its anthropological significance, has also proven to be a fertile source of insights for students of political culture. Turner's study develops the idea of liminal groups and practices, existing at the outer edge of a society and used by the society as foils for the creation of its own identity. Aristide R. Zolberg, in Moments of Madness, 2 Pol. \& Soc'y 183 (1972), has shown how anthropological insights may illuminate the significance of periods of extraordinary political enthusiasm.

Several interpretive scholars have drawn upon the collection of theoretical techniques often referred to as "deconstruction." John E. Toews usefully interprets and criticizes these techniques in Intellectual History after the Linguistic Turn: The Autonomy of Meaning and the Irreducibility of Experience, 92 Am.Hist.Rev. 879 (1987). Hermeneutics, another school of thought native to textual studies, has also provided inspiration to students of political culture. Two particularly influential studies bringing hermeneutics to bear on the problems of the social sciences are Charles Taylor, Interpretation and the Sciences of Man, 25 Rev.Metaphysics 3 (1971), and Paul Ricoeur, The Model of the Text: Meaningful Action Considered as Text, reprinted in Paul Ricoeur, Hermeneutics and the Human Sciences (1981).

Interpreters of political culture also draw upon the works of political scientists who have considered how American politics 
shapes and educates public opinion, and how the public mind in turn governs the progress of American politics. A notable contribution to this broad and well-developed category of scholarship is Joseph Cropsey's The United States as Regime and the Sources of the American Way of Life, in Robert H. Horwitz's The Moral Foundations of the American Republic (3rd ed. 1986), which reflects upon how the character of the people mediates between theory and practice in the American polity. Of more immediate relevance to lawyers is Ralph Lerner's The Supreme Court as Republican Schoolmaster, first published at 1967 S.Ct.Rev. 127 (1967) and reprinted in Ralph Lerner, The Thinking Revolutionary (1987), commenting on the ways in which early American Supreme Court justices undertook to provide Americans with a civic education. Harvey C. Mansfield, Jr.'s new book, America's Constitutional Soul (forthcoming), shows the significance of classical political philosophy for the understanding of American collective identity.

Finally, a growing number of studies seek to explicate the connections between political rhetoric and political action in the American regime. Jeffrey $K$. Tulis, in The Rhetorical Presidency (1987), uses variations in the rhetorical practices of American presidents to illustrate the way in which different understandings of constitutional principles have shaped American political life at both the architectonic and particular levels. Glen E. Thurow and Jeffrey D. Wallin have collected a series of essays on American rhetoric in their volume, Rhetoric and American Statesmanship (1984). 